\title{
DEVELOPMENT OF SUSTAINABLE BUILDING BLOCKS WITH TYRE WASTE, FLYASH AND LIME
}

\author{
Sumalatha J, Niranjan G.H. Prashant Sunagar and Abhishek Kumar Chaurasiya \\ Department of Civil Engineering, M S Ramaiah Institute of Technology, Bangalore, India \\ Manish S Dharek \\ Department of Civil Engineering, BMS Institute of Technology, Bangalore, India
}

\begin{abstract}
Land-filling waste tyres and fly ash is undesirable due to reduction in available sites to dispose the huge quantities of these wastes. Utilization of fly ash as a byproduct in the construction industry reduces technical and environmental problems. The present study aims at the utilization of crumbed rubber waste and fly ash as partial replacements for aggregates. An attempt is made to manufacture concrete blocks with crumbed rubber, cement, fly ash and lime as ingredients. The engineering properties such as water absorption, flexural strength, dimensionality test, block density and compressive strength of the concrete blocks were determined and compared with the codal provisions. The weight of rubcrete blocks were found to be about 25\% less when compared with the ordinary blocks. The block density of rubcrete blocks was found to be around $1723 \mathrm{~kg} / \mathrm{m}^{3}$ which is slightly lower than the prescribed limits. The flexural strength of block was found to be three times higher than the normal limits. The compressive strength of the blocks was slightly lower than the minimum prescribed in the Indian Standards. The water absorption of rubcrete blocks was found to be $6.36 \%$. The design approach developed to manufacture blocks using rubber powder and fly ash is useful to produce a sustainable construction material.
\end{abstract}

Keywords: Building Blocks, Tyre Waste, Flyash, Lime.

Cite this Article: Sumalatha J, Manish S Dharek, Niranjan G.H., Prashant Sunagar and Abhishek Kumar Chaurasiya, Development of Sustainable Building Blocks with Tyre Waste, Flyash and Lime. International Journal of Civil Engineering and Technology, 11(5), 2020, pp. 93-104. https://iaeme.com/Home/issue/IJCIET?Volume=11\&Issue=5

\section{INTRODUCTION}

The increasing quantity of waste tyres resulted from the increase in number of vehicles and traffic volume is one of the major problems to the environment. The quick development of the automobile industry and standard of living of people, the quantity of tyre waste increased 
rapidly. Generally, the waste tyres which have been categorized as municipal solid waste are thrown randomly by the users in open areas in improper ways which causes pollution. End-oflife tyres or waste tyres are a chronic environmental issue globally as their disposal on land not only pose threat to the environment but also turn their dumpsites as breeding basis for rats and mosquitoes. Every year, thousands of tyres reach landfills and dumpsites across the world, which causes extensive environmental and hazardous problems including fire hazards. The disposal of waste tyres also causes ecological imbalance as the dump areas effect the biodiversity. The toxic components in the tyres may cause soil and water pollution. Accidentally, if the tyres start burning, toxic fumes will be generated and cause air pollution. Also, the melted tyres produce oil that will contaminate nearby soil and water resources. Due to industrialization across the world, the production of motor vehicles has been growing and causing rapid increase in the tyre wastes. According to the report of International Organization of Motor Vehicle Manufacturers (OICA, 2017), there was about 85\% increase in the production of cars across the world. In 2016 alone, there was an increase in production of about $7 \%$ when compared with the previous year and the number of vehicles produced in this year were around 97 million (OICA, 2017). According to the report of World Business Council for Sustainable Development (WBCSD), the quantity of waste tyres generated in 2016 was around 25.6 million tons (WBCSD, 2018).

There was extensive research underwent on the utilization of waste materials in construction industry and attempts were made to produce cost effective materials using different kinds of wastes. This eventually reduces the dumping problems and burden on landfills. The utilization of fly ash in concrete was studied by Yilmaz et al., 2009. They examined the properties of fresh and hardened concrete and found that the 28-day strength of high-strength concrete produced using class $\mathrm{C}$ fly ash can be $100 \mathrm{MPa}$ or more. The performance of high volume fly ash concrete with a silica fumes in smaller quantities was also studied and found that the 28-day compressive strength of these mixtures was in the range of $30-40 \mathrm{MPa}$. The properties of concrete with tyre rubber waste were studied by Skripkiūnas et al, 2007. They compared the strains of concrete prepared with and without rubber waste corresponding to same compressive strength. They observed that the strains of rubberized concrete was $56 \%-63 \%$ (after the static loading) and $219 \%-360 \%$ (after the unloading) higher than the non-rubberized concrete. The properties of concretes prepared with the replacement of coarse aggregates by chipped tyres and with the replacement of cement by powder tyre crumbs were studied by Eshmaiel Ganjiana et al, 2009. They examined the compressive strengths of concretes corresponding to the same replacement ratios of 5\%, $7.5 \%$, and 10 . The compressive strength of concrete was found to decrease with increase in rubber content. It was also concluded that rubberized concrete made with chipped rubber showed less strength than concrete made with crumb rubber.

Batayneh and Marie, 2008 studied the effect of different percentages of crumb rubber (obtained from waste tyres) as fine aggregate on the properties of concrete. It was concluded that the increase in rubber leads to decrease in the compressive strength. Their results indicated that the utilization of waste tyres in higher percentages such as $20 \%, 40 \%, 60 \%$, $80 \%$, and $100 \%$ is possible. Eldin et al, 1993 examined the variations in the mechanical properties of concrete made with different sizes of tyre chips as aggregate and with the method of grinding the tyres. Losses of up to $85 \%$ of the compressive strength and up to $50 \%$ of the tensile strength, depending on the percentage of rubber, were observed. Najim and Hall (2012) used the crumb rubber of waste tyres both as coarse and fine aggregates to prepare self compacting concrete (SCC). They used 2-6 mm size crumb rubber in different proportions such as $5 \%, 10 \%$ and $15 \%$ by weight of aggregates. They found that the decrease in compressive strength of rubberized self compacting concrete is similar to that of plain rubberized concrete. Nahla Naji Hilal, 2017 investigated the effect of crumb rubber size and 
its content on hardened characteristics of self-compacting concrete. They found that the increase in rubber size and quantity cause decrease in the static elastic modulus and bond strength similar to the trend of both compressive strength and tensile strength. The flexural and compressive strengths decrease with the increase in the rubber content (Aslani, 2016).

The properties of rubber that is used in the concrete will not affect the mechanical properties of concrete and the strength of concrete always decreases with the addition of any kind of rubber (Topçu, 1995; Cairns et al, 2004; Taha et al, 2008; Bignozzi \& Sandrolini, 2006; Zheng et al, 2008). The decreasing trend in the strength properties of concrete, increases with the increase in rubber content which is due to the separation of rubber particles from the concrete mix when the load is applied. Yet, the strength properties of rubberized self compacting concrete were higher than those of plain rubberized concrete ( $\mathrm{Li}$ et al, 2004). The ductility and strain characteristics of self compacting concrete enhances with the inclusion of rubber waste in the concrete (Güneyisi et al, 2004; Batayneh and Marie, 2008; Najim and Hall, 2012). The inclusion of rubber waste in self compacting concrete also enhances the impact resistance of concrete (Sofi, 2018). On the contrary, the rubberized self compacting concrete exhibits higher crack size than the non-rubberized SCC (Fattuhi \& Clark, 1996). Khatib and Bayomy, 1999, Hernandez and Barluenga, 2004, Albano et al. 2005, Gesoğlu and Güneyisi, 2007 and Wong and Ting 2009 reported that there is a decrease in the slump value for the rubberized SCC. Yet, the slump of the rubberized SCC can be improved by replacing the cement partially with fly ash and by using higher dosages of superplasticizers. The slump value of SCC also increases with the increase in fly ash content (Uysal \& Sumer, 2011), nevertheless there is a decrease in the strength of SCC with the incorporation of fly ash into SCC (Khatib, 2008; Guneyisi et al, 2009; Şahmaran et al, 2009). It was also reported that the slump value of SCC also increases when the cement is partially replaced with lime stone powder. The optimum content of lime stone powder in SCC as reported by Uysal \& Yilmaz, 2011 was $20 \%$. The porosity and water absorption of rubberized SCC are higher than those of plain cement concrete due to the higher air entrapment happened at the time of mixing (Hernández \& Barluenga, 2004; Siddique \& Naik, 2004; Bignozzi \& Sandrolini, 2006; Batayneh et al, 2008).

Several research works are also in progress for effective utilization of crumbed rubber as an ingredient in concrete blocks, since concrete blocks invariably make use of sand and stone dust as fine aggregate to fill the voids in the blocks. The present study aims at the utilization of crumbed rubber tyre waste in SCC to develop concrete blocks. It was proposed to arrive at the optimum percentage of replacement of sand with crumbed rubber by evaluating different percentages of crumb rubber. The production process of rubberized concrete blocks (rubcrete blocks) and their engineering properties were discussed. The engineering properties of rubcrete blocks such as water absorption, flexural strength, dimensionality test, block density, compressive strength of the concrete blocks have been determined and compared with the codal provisions.

\section{MATERIALS AND METHODS}

\subsection{Cement, Flyash and Sand}

The cement used for the investigation was ordinary Portland cement (43 grade). It confirmed to the requirement of Indian Standard specification IS8112-1989. The cement possessed a normal consistency of $30.5 \%$. The Initial and final setting times of cement were 85 minutes and 10 hours respectively. Sieve analysis was conducted to determine the particle size distribution of sand and it was identified as Zone 2 class with fineness modulus of 3.42. The 
Le-Chatelier method was used to determine the specific gravity of the fly ash and cement, where the funnel is filled with kerosene, were use of water to the cement causes setting so kerosene is used and cement is added in known quantity and the specific gravity is determined. Specific gravity of cement, flyash and sand obtained were 3.15, 2.72 and 2.81 respectively.

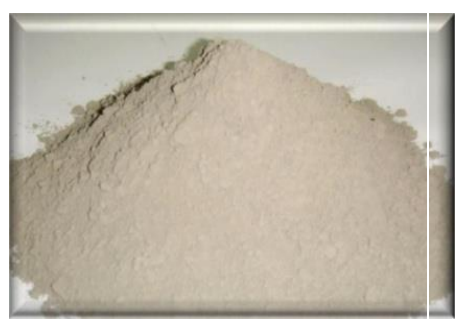

Cement

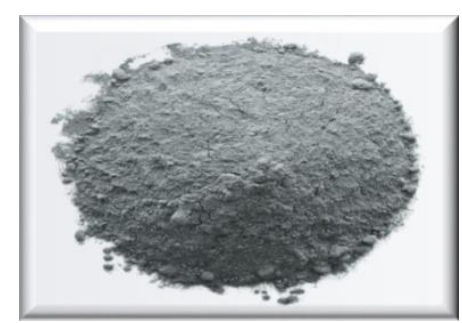

Flyash

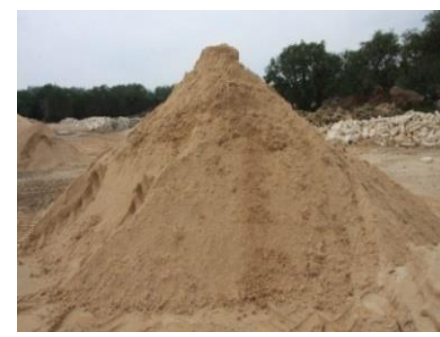

Sand

Figure 1 Cement, Flyash and Sand used in the study

\subsection{Crumbed Rubber \& Lime}

The specific gravity of Crumbed Rubber and lime obtained were 0.91 and 2.06 respectively. The fineness modulus of Crumbed Rubber obtained from the sieve analysis is 3.98 which indicate the particles are coarser.

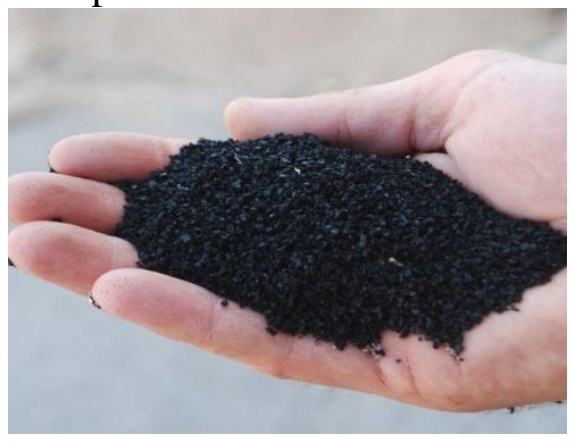

Crumbed rubber

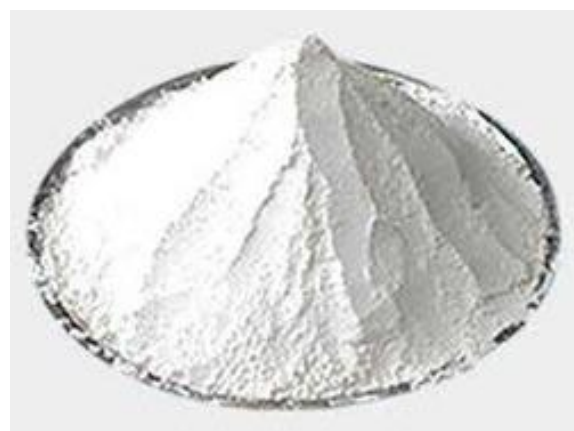

Lime

Figure 2 Crumbed rubber and Lime used in the study

\subsection{Preparation of Blocks using Egg Laying Machine}

To prepare the rub Crete blocks, different trials mixes were made as per the IS code 10262:2009. A mould of $150 \times 150 \times 150 \mathrm{~mm}$ is used for the trial cast for determining the strength of the cube. The cubes are made in accordance to the trials made such as 1:5 and 1:9 trails and with percentage of volume for the sand replaced by crumbed rubber and cement is replaced with the fly ash up to some percentage for each trail vary with the percentage and cubes are casted according to the percentage of replacement. The proportions of the materials for 1:5 and 1:9 are given in Tables 1 and 2 . 
Sumalatha J, Manish S Dharek, Niranjan G.H., Prashant Sunagar and Abhishek Kumar Chaurasiya

Table 1 RATIO 1:5 (in percentage)

\begin{tabular}{|c|c|c|c|c|}
\hline \multicolumn{2}{|c|}{ In 1:5 where it is 1 part of the mix } & \multicolumn{2}{c|}{ In 1:5 where it is 5 part of the mix } \\
\hline CEMENT & LIME & FLY ASH & RUBBER & SAND \\
\hline 70 & 10 & 30 & 80 & 20 \\
\hline 50 & 10 & 40 & 60 & 40 \\
\hline 30 & 10 & 60 & 40 & 60 \\
\hline
\end{tabular}

Table 2 RATIO 1:9 (in percentage)

\begin{tabular}{|c|c|c|c|c|}
\hline \multicolumn{2}{|c|}{ In 1:9 where it is 1 part of the mix } & \multicolumn{2}{c|}{ In 1:9 where it is 5 part of the mix } \\
\hline CEMENT & LIME & FLY ASH & RUBBER & SAND \\
\hline 70 & 10 & 30 & 80 & 20 \\
\hline 50 & 10 & 40 & 60 & 40 \\
\hline 30 & 10 & 60 & 40 & 60 \\
\hline
\end{tabular}

In the site, the blocks are made with the Egg Laying machine (Fig. 3) for finding the suitable trial mix instead of normal sand $\mathrm{M}$ sand is used. The overall specifications of Egg Laying Machine are given in Table 3. The prepared mixture of concrete is placed in the machine and when it is operated the machine compact the bricks in place, later it is moved forward and the process will be repeated. The average density of the blocks was $2.036 \mathrm{~g} / \mathrm{cc}$.

Table 3 Specifications of Egg Laying machine

\begin{tabular}{|l|c|}
\hline \multicolumn{1}{|c|}{ Parameter } & Specification \\
\hline Area of Mould & $600 \mathrm{~mm} \mathrm{x} \mathrm{800} \mathrm{mm} \mathrm{x} \mathrm{250} \mathrm{mm}$ \\
\hline Height of the block & $200 \mathrm{~mm}$ \\
\hline Cycle Time (s) & $90 \mathrm{~s}$ \\
\hline Number of cycles per hour & $40 \mathrm{nos}$. \\
\hline Number of blocks per hour & $400 \mathrm{nos}$. \\
\hline Capacity of Pump Motor & $3.0 \mathrm{Hp}$ \\
\hline Capacity of Vibrator Motor & $2.0 \mathrm{Hp}$ \\
\hline Capacity of Travel Motor & $0.5 \mathrm{Hp}$ \\
\hline
\end{tabular}

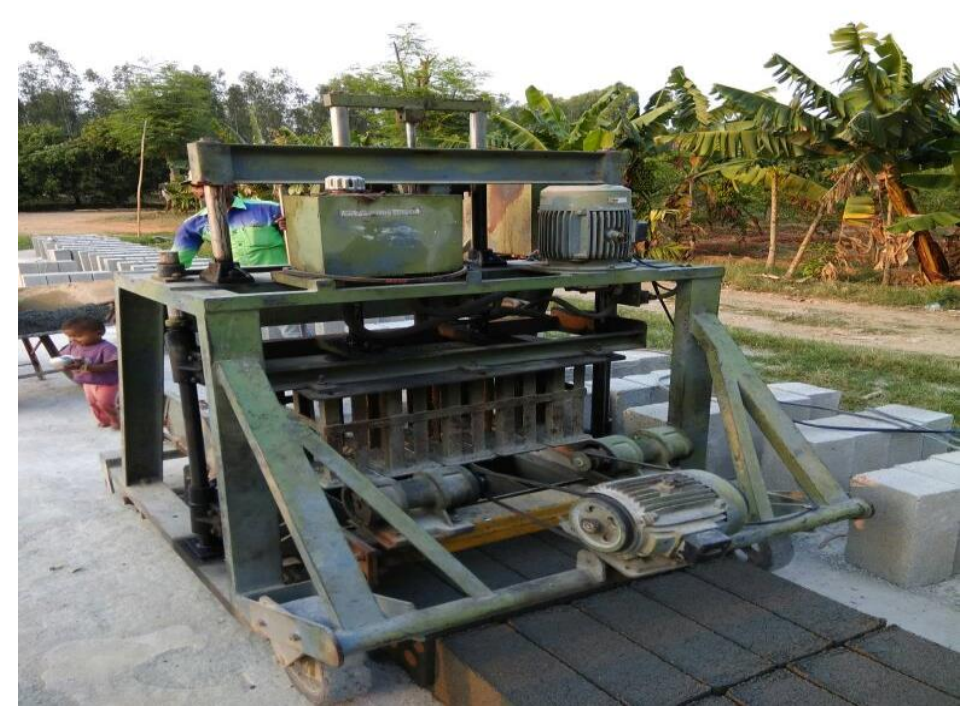

Figure 3 Photograph of Egg Laying Machine 


\subsection{Lime Reactivity Test}

Lime reactivity test was conducted to study the reactivity of the pozzolanic substance (fly ash) with hydrated lime as specified in IS1727. Six cubes of standard size 50x50x50mm were casted with a water/cement ratio of 0.7 and the strength developed was determined. The average strength of lime reactivity cubes for 7days was $0.225 \mathrm{MPa}$.

\subsection{Flexural Strength Test}

In this method the flexural strength is determined for the Rubcrete blocks. The modulus of rupture for concrete was determined by transverse bending test using two point load transfer method.

\subsection{Compressive Strength Test}

The Ultrasonic Testing machine was used to know the strength of the blocks, crack occurrence, size and shape is known. Generally strength is of target strength calculated in mix design procedure. The recommendation given by IS: 2185 part 1, 2 were followed for carrying out tests for testing blocks

\subsection{Water Absorption Test}

This test was conducted with the same procedure of fine aggregate as per IS: 2185 part1. Three specimens were randomly chosen and their weight is obtained (W2). The test specimens were immersed in water for 24 hours. The blocks were then removed from the water and were allowed to drain for one minute. Visible surface water was removed with a damp cloth, and immediately weighed (W1).

$$
\text { Water Absorption }=\left(\frac{\mathrm{W} 1-\mathrm{W} 2}{W 2}\right) \times 100 \%
$$

The water absorption being the average of three units should not be more than $10 \%$.

\subsection{Weight of Blocks}

The average weight of the block is $20.68 \mathrm{~kg}$. The coefficient of variation was found to be $4.15 \%$. The weight of the conventional solid blocks $(150 \mathrm{~mm})$ in the Bengaluru region is around $25 \mathrm{~kg}$.The weight of the rubcrete blocks was found to be about $20 \%$ less when compared with conventional solid blocks.

\subsection{Block Density}

The average Block density was found to be $1723 \mathrm{~kg} / \mathrm{m}^{3}$. The coefficient of variation was found to be $4.15 \%$. The value recommended in table2 IS 2185 part1 is $1800 \mathrm{~kg} / \mathrm{m}^{3}$. This was found to be slightly lower than the prescribed limits. The coefficient of variation was found to be $4.15 \%$. The value recommended in table 2 IS 2185 part 1 is $1800 \mathrm{~kg} / \mathrm{m}^{3}$. This was found to be slightly lower than the prescribed limits.

\section{RESULTS AND DISCUSSIONS}

\subsection{Compressive Strength of Rubcrete Blocks}

The compressive strength of rubcrete blocks and locally available ordinary concrete blocks were determined and compared. The photograph showing the compression testing is shown in Fig. 4. The compressive strength of rubcrete blocks was presented in table 4. It was observed the mean compressive strength of $150 \mathrm{~mm}$ solid blocks was $2.0 \mathrm{MPa}$. This was less than the minimum prescribed in the IS2185. According to the IS: 2185 part 1, the solid concrete blocks should have minimum compressive strength of 3.2 MPa. Further study needs to be 
Sumalatha J, Manish S Dharek, Niranjan G.H., Prashant Sunagar and Abhishek Kumar Chaurasiya

under taken to improve the compressive strength of blocks. The coefficient of variation in the 28 days strength of the rubcrete blocks with ordinary concrete blocks was found as $27.64 \%$ (Table 5).

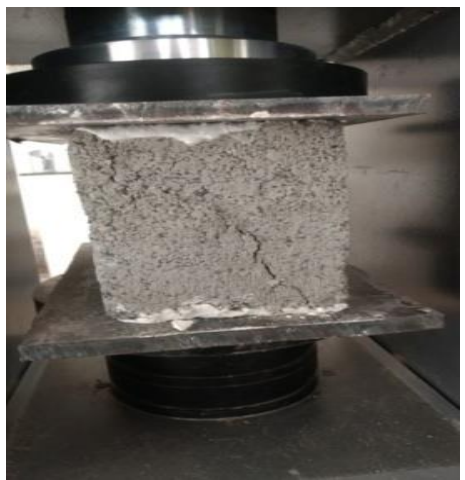

Rubcrete block

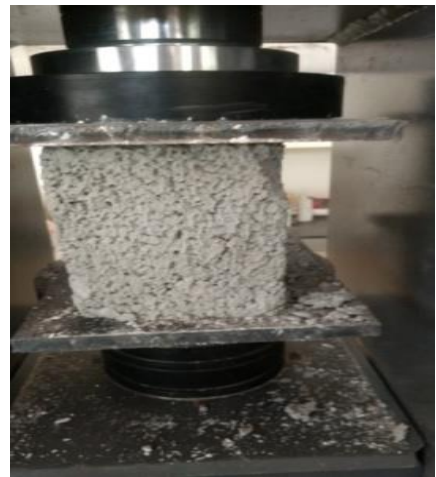

Ordinary concrete block

Figure 4 Compression testing of rubcrete and ordinary blocks

Table 4 Compressive Strength of blocks tested

\begin{tabular}{|c|c|c|c|c|}
\hline Mix Ratio & $\begin{array}{c}\text { Volume Replaced: } \\
1 \text { for cement content and } 5 \text { for } \\
\text { aggregate }\end{array}$ & S. No & $\begin{array}{c}\text { Weight } \\
\text { (kg) }\end{array}$ & $\begin{array}{l}\text { Compressive } \\
\text { strength ( MPa) }\end{array}$ \\
\hline \multirow{9}{*}{$\begin{array}{l}\text { 1:5 Mix } \\
\text { Ratio }\end{array}$} & \multirow{3}{*}{$70 \%$ C $10 \%$ L \& $20 \% \mathrm{~F}, 80 \% \mathrm{R} \& 20 \% \mathrm{~S}$} & 1 & 1.34 & 1 \\
\hline & & 2 & 1.4 & 1.19 \\
\hline & & 3 & 1.38 & 1.04 \\
\hline & \multirow{3}{*}{$50 \%$ C $10 \%$ L \& $40 \% \mathrm{~F}, 60 \% \mathrm{R} \& 40 \% \mathrm{~S}$} & 4 & 1.58 & 1.25 \\
\hline & & 5 & 1.6 & 1.25 \\
\hline & & 6 & 1.48 & 1.2 \\
\hline & \multirow{3}{*}{$30 \%$ C $10 \%$ L \& $60 \% \mathrm{~F}, 40 \% \mathrm{R} \& 60 \% \mathrm{~S}$} & 7 & 1.72 & 1.55 \\
\hline & & 8 & 1.78 & 1.6 \\
\hline & & 9 & 1.78 & 1.5 \\
\hline \multirow{9}{*}{$\begin{array}{l}\text { 1:9 Mix } \\
\text { Ratio }\end{array}$} & \multirow{3}{*}{$70 \%$ C $10 \%$ L \& $20 \% \mathrm{~F}, 80 \% \mathrm{R} \& 20 \% \mathrm{~S}$} & 10 & 1 & 0.235 \\
\hline & & 11 & 1.04 & 0.235 \\
\hline & & 12 & 1.1 & 0.265 \\
\hline & \multirow{3}{*}{$50 \%$ C $10 \% \mathrm{~L} \& 40 \% \mathrm{~F}, 60 \% \mathrm{R} \& 40 \% \mathrm{~S}$} & 13 & 1.5 & 0.535 \\
\hline & & 14 & 1.46 & 0.53 \\
\hline & & 15 & 1.46 & 0.54 \\
\hline & \multirow{3}{*}{$30 \%$ C $10 \%$ L \& $60 \% \mathrm{~F}, 40 \% \mathrm{R} \& 60 \% \mathrm{~S}$} & 16 & 1.6 & 0.725 \\
\hline & & 17 & 1.7 & 0.7 \\
\hline & & 18 & 1.72 & 0.675 \\
\hline
\end{tabular}

[C: Cement; L: Lime; F: Fly Ash; R: Crumbed Rubber; S: Sand]

Table 5 Compressive Strength of Rubcrete Blocks

\begin{tabular}{|l|c|c|c|c|}
\hline Type of blocks & S. No & Weight $(\mathbf{k g})$ & $\begin{array}{c}\text { 28 days Strength } \\
\text { (MPa) }\end{array}$ & $\begin{array}{c}\text { Coefficient of } \\
\text { variation (\%) }\end{array}$ \\
\hline \multirow{4}{*}{ Rubcrete Blocks } & 1. & 20.63 & 1.548 & \\
\cline { 2 - 4 } & 2. & 19.76 & 1.55 & \\
\cline { 2 - 4 } & 3. & 20.72 & 2.05 & \multirow{2}{*}{27.63} \\
\cline { 2 - 4 } & 4. & 20.12 & 2.067 & \\
\cline { 2 - 4 } & 5. & 19.2 & 1.516 & \\
\hline Ordinary Blocks & 6. & 21.5 & 6.9 & \\
\hline
\end{tabular}




\subsection{Flexural Strength of Rubcrete Blocks}

The flexural strength of the rubcrete blocks and ordinary concrete blocks were determined and the coefficient of variation in the flexural strength was estimated. The photograph showing the flexural strength testing is shown in Fig. 5. The values of flexural strength of the rubcrete blocks were presented in table 6 . The average flexural strength of the rubcrete block was 1.0MPa. The coefficient of variation was found to be $17.65 \%$. The flexural strength of block was found to be three times higher than the normal limits $(10 \%$ of the compressive strength).This was due to presence of crumbed rubber fibers present in the mix which have shown resistance under flexural loading. During the testing it was also observed that rubcrete blocks showed good resistance under flexural loading for a longer duration when compared with conventional solid blocks.

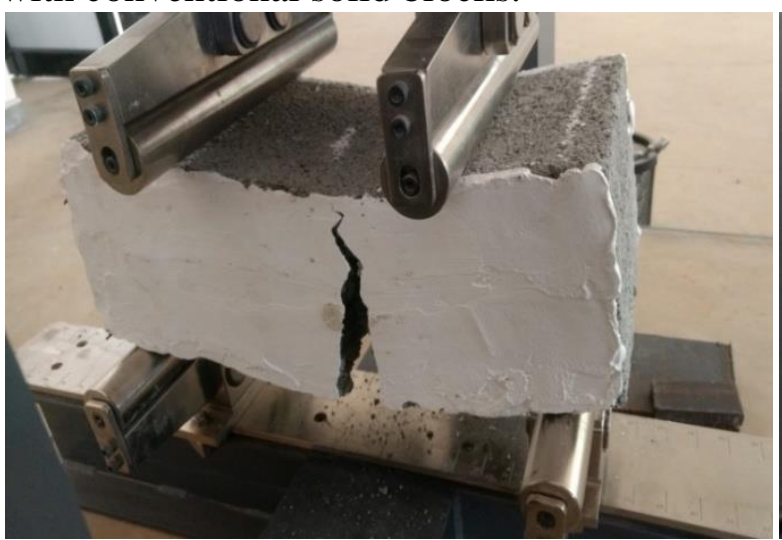

Rubcrete block

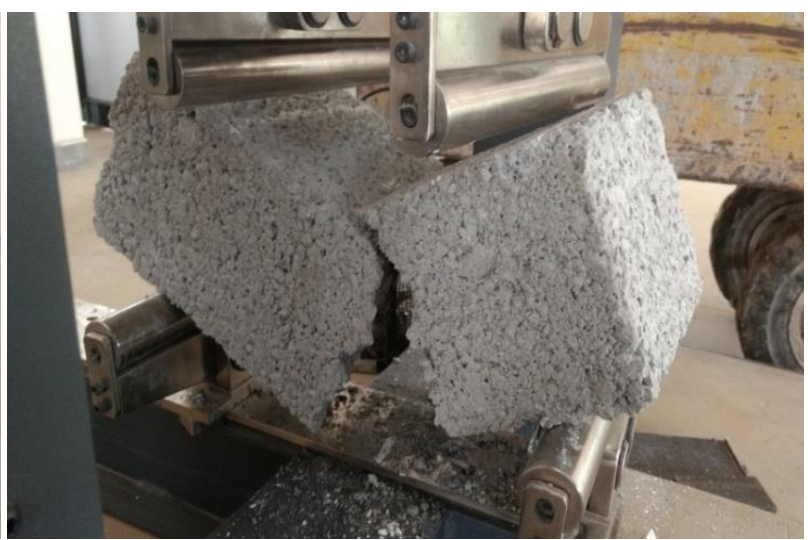

Ordinary concrete block

Figure 5 Flexural strength testing of rubcrete and ordinary blocks

Table 6 Flexural Strength of Rubcrete Blocks

\begin{tabular}{|c|c|c|c|c|}
\hline Type of blocks & S. No & Weight $(\mathbf{k g})$ & $\begin{array}{c}\text { 28 days Strength } \\
\text { (MPa) }\end{array}$ & $\begin{array}{c}\text { Coefficient of } \\
\text { variation (\%) }\end{array}$ \\
\hline \multirow{3}{*}{ Rubcrete Blocks } & 1. & 19.64 & 0.879 & \\
\cline { 2 - 4 } & 2. & 21.72 & 0.983 & \\
\cline { 2 - 4 } & 3. & 20.94 & 0.891 & \multirow{2}{*}{17.65} \\
\cline { 2 - 4 } & 4. & 21.56 & 1.31 & \\
\cline { 2 - 4 } & 5. & 19.98 & 0.879 & \\
\hline Ordinary Blocks & 6. & 20.24 & 0.88 & \\
\hline
\end{tabular}

\subsection{Dimensionality Test}

Figs 6, 7 and 8 show the procedure of measurements in dimensionality test. The blocks placed along its width to know the perfect width for 10 blocks placed next to each other and was measured as $1.55 \mathrm{~m}$. The blocks placed along its length to know the perfect length for 10 blocks placed next to each other was measured as $4.08 \mathrm{~m}$. The blocks placed along its height to know the perfect height for 10 blocks placed next to each other was found as $2.0 \mathrm{~m}$. The average dimension of the 6 " $(150 \mathrm{~mm})$ block was $4.08 \times 1.55 \times 2.0 \mathrm{~m}$. According to IS 2185 part 1 the maximum variation in the length of the units shall not be more than $+5 \mathrm{~mm}$ and maximum variation in height and width of the unit, not more than $+3 \mathrm{~mm}$. However the average length of the blocks was found to be slightly higher than the prescribed limits. 
Sumalatha J, Manish S Dharek, Niranjan G.H., Prashant Sunagar and Abhishek Kumar Chaurasiya

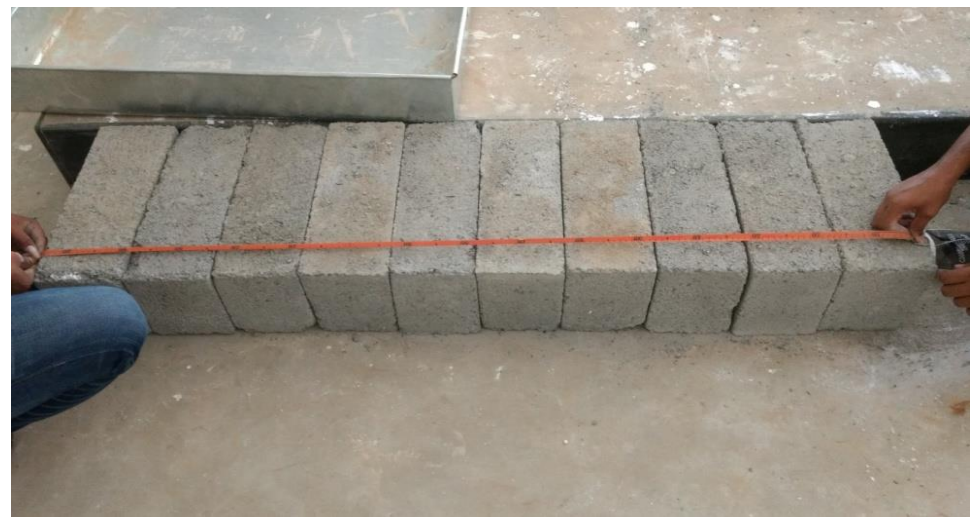

Figure 6 Dimensionality test along width

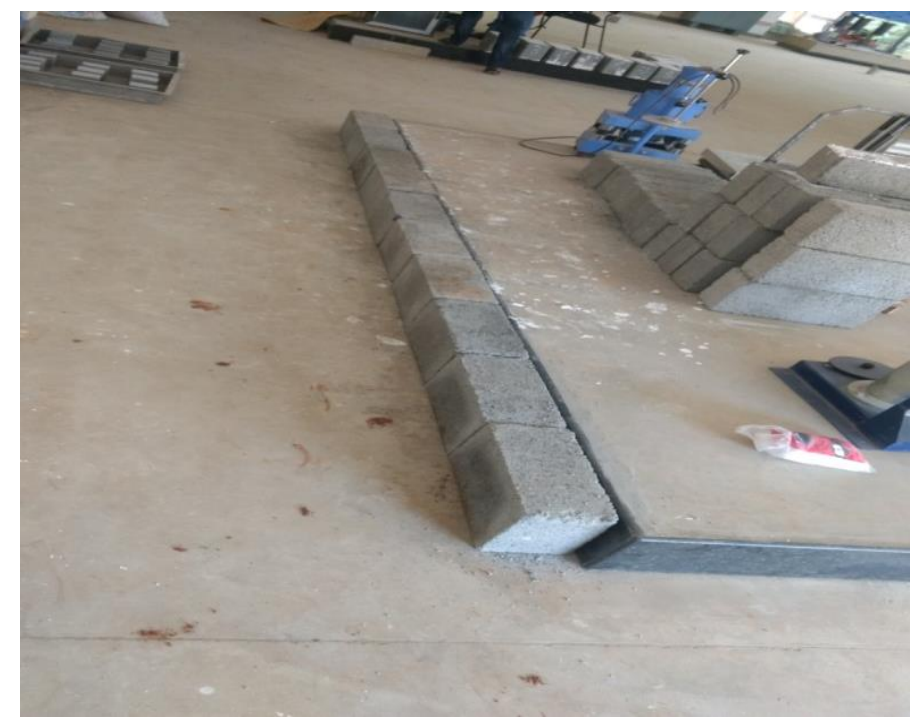

Figure 7 Dimensionality test along length

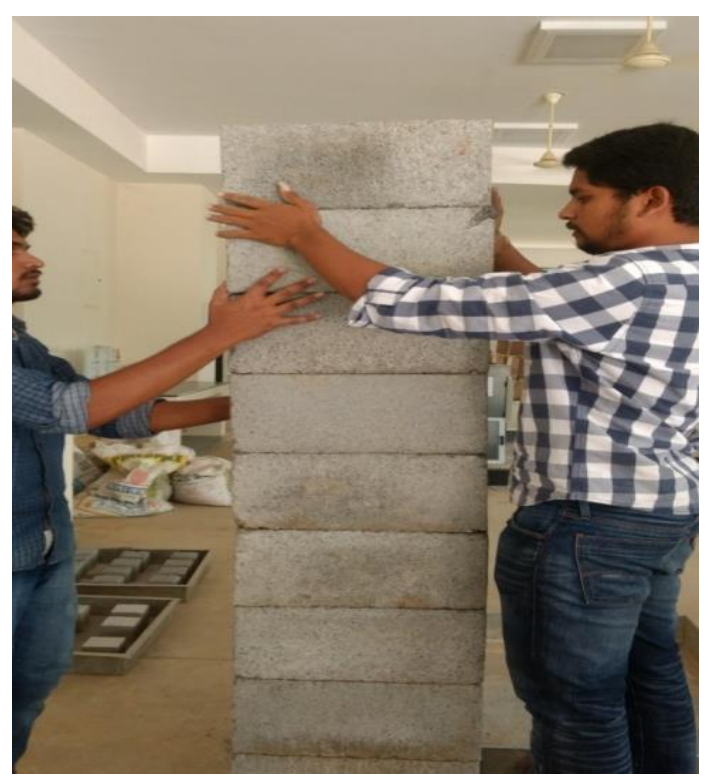

Figure 8 Dimensionality test along height 


\subsection{Water Absorption Test}

The water absorption of the Rubcrete blocks and ordinary concrete blocks were determined and the coefficient of variation is estimated. The \% water absorption of the blocks tested are shown in Table 7. The average value of water absorption of the Rubcrete blocks was found as $6.36 \%$. The coefficient of variation was found to be $22.77 \%$. The test results were found to be in the specified range i.e. below $10 \%$ as per the IS: 2185 part1.

Table 7 Water absorption of blocks

\begin{tabular}{|c|c|c|c|c|}
\hline \multirow{2}{*}{ Type of blocks } & $\begin{array}{c}\text { Weight of Wet } \\
\text { Block (kg) }\end{array}$ & $\begin{array}{c}\text { Weight of Dry } \\
\text { Block (kg) }\end{array}$ & $\begin{array}{c}\text { Water Absorption } \\
\text { (\%) }\end{array}$ & $\begin{array}{c}\text { Coefficient } \\
\text { of } \\
\text { variation } \\
(\%)\end{array}$ \\
\hline \multirow{2}{*}{ Rubcrete Block } & 21.960 & 20.380 & 7.752 & \multirow{2}{*}{22.77} \\
\cline { 2 - 4 } & 22.440 & 21.40 & 4.86 & \\
\hline Average & 22.34 & 20.980 & 6.482 & \\
\hline Ordinary Block & 25.34 & 24.180 & \multicolumn{2}{|c|}{$6.36 \%$} \\
\cline { 2 - 4 }
\end{tabular}

\section{CONCLUSIONS}

- The weight of the rubcrete blocks were found to be about $25 \%$ less when compared with the ordinary concrete blocks.

- The block density of rubcrete blocks was found to be around $1723 \mathrm{~kg} / \mathrm{m}^{3}$. The value recommended in Table 2 of IS: 2185 part 1 is $1800 \mathrm{~kg} / \mathrm{m}^{3}$. This was found to be slightly lower than the prescribed limits.

- The average dimension of the 6" $(150 \mathrm{~mm})$ block was estimated as $408 \times 155 \times 200 \mathrm{~mm}$ where the average length of the blocks was found to be slightly higher than the prescribed limits.

- The flexural strength of the rubcrete blocks was estimated as three times higher than the normal limits (10\% of the compressive strength) as the presence of crumbed rubber fibers offer resistance under flexural loading. It was also observed that the rubcrete blocks exhibited good resistance under flexural loading for a longer duration when compared with ordinary concrete blocks.

- The average compressive strength of the rubcrete blocks was found as $2.0 \mathrm{MPa}$ which is less than the minimum prescribed value in the IS: 2185 . The coefficient of variation when compared with ordinary concrete blocks was measured as $27.64 \%$.

- The water absorption of rubcrete blocks was found to be $6.36 \%$. The test results were found to be in the specified range i.e. below $10 \%$ as per the IS: 2185 part1.

\section{REFERENCES}

[1] Albano C, Camacho N, Reyes J, Feliu JL, Hernández M (2005) Influence of scrap rubber addition to Portland I concrete composites: destructive and non-destructive testing. Compos Struct 71:439-446. https://doi.org/10.1016/j.comps truct.2005.09.037 81.

[2] Batayneh MK, Marie I, Asi I (2008) Promoting the use of crumb rubber concrete in developing countries. Waste Manag 28:2171-2176. https://doi.org/10.1016/j.wasma n.2007.09.035

[3] Batayneh MK, Marie I, Asi I (2008) Promoting the use of crumb rubber concrete in developing countries. Waste Manag 28:2171-2176. https://doi.org/10.1016/j.wasma n.2007.09.035 
[4] Batayneh, M. K., Marie, I., \& Asi, I. (2008). Promoting the use of crumb rubber concrete in developing countries. Waste management, 28(11), 2171-2176.

[5] Bignozzi MC, Sandrolini F (2006) Tyre rubber waste recycling in self-compacting concrete. Cem Concr Res 36:735-739. https://doi.org/10.1016/j.cemconres.2005.12.011

[6] Cairns R, Kew H, Kenny M (2004) The use of recycled rubber tyres in concrete construction. In: Sustainable waste management and recycling. Thomas Telford Ltd, London

[7] Eldin, N. N., \& Senouci, A. B. (1993). Rubber-tyre particles as concrete aggregate. Journal of materials in civil engineering, 5(4), 478-496.

[8] Eshmaiel Ganjiana, Morteza Khoramib, Ali Akbar Maghsoudic" Scrap-tyre-rubber replacement for aggregate and filler in concrete" Construction and Building Materials, Volume 23, Issue 5, May 2009, Pages 1828- 1836.

[9] Farhad Aslani, Mechanical Properties of Waste Tyre Rubber Concrete Mechanical Properties of Waste Tyre Rubber Concrete, J. Mater. Civ. Eng., 28 (3) (2016), p. 04015152

[10] Fattuhi NI, Clark LA (1996) Cement-based materials containing shredded scrap truck tyre rubber. Constr Build Mater 10:229-236. https://doi.org/10.1016/0950-0618(96)00004-9

[11] Gesoğlu M, Güneyisi E (2007) Strength development and chloride penetration in rubberized concretes with and without silica fume. Mater Struct 40:953-964. https://doi. org/10.1617/s11527-007-9279-0

[12] Güneyisi E, Gesoglu M, Özbay E (2009) Evaluating and forecasting the initial and fnal setting times of self-compacting concretes containing mineral admixtures by neural network. Mater Struct 42:469-484. https://doi.org/10.1617/s11527-008-9395-5 47.

[13] Güneyisi E, Gesoğlu M, Özturan T (2004) Properties of rubberized concretes containing silica fume. Cem Concr Res 34:2309-2317. https://doi.org/10.1016/j.cemco nres.2004.04.005 74 .

[14] Hernández-Olivares F, Barluenga G (2004) Fire performance of recycled rubber-filled high-strength concrete. Cem Concr Res 34:109-117. https://doi.org/10.1016/S00088846(03)00253-9

[15] Hernández-Olivares F, Barluenga G (2004) Fire performance of recycled rubber-filled high-strength concrete. Cem Concr Res 34:109-117. https://doi.org/10.1016/S00088846(03)00253-9

[16] Hilal, N. N. (2017). Hardened properties of self-compacting concrete with different crumb rubber size and content. International Journal of Sustainable Built Environment, 6(1), 191-206.

[17] IS: 10262 (2009), Concrete Mix Proportioning - Guidelines.

[18] IS: 1727 (1967), Methods of test for pozzolanic materials

[19] IS: 2185 (2005), part 1, Concrete masonry Units - Specification.

[20] IS: 8112 (1989), Specifications for 43 grade Ordinary Portland Cement

[21] K.B. Najim, M.R. Hall, Mechanical and dynamic properties of self-compacting crumb rubber modified concrete Construct. Build. Mater., 27 (2012), pp. 522-524

[22] Khatib JM (2008) Performance of self-compacting concrete containing fy ash. Constr Build Mater 22:1963-1971. https:// doi.org/10.1016/j.conbuildmat.2007.07.01146.

[23] Khatib Z, Bayomy F (1999) Rubberized portland cement concrete. J Mater Civ Eng 11:206-213 
[24] Li G, Stubblefield MA, Garrick G, Eggers J, Abadie C, Huang B (2004) Development of waste tyre modified concrete. Cem Concr Res 34:2283-2289.

https://doi.org/10.1016/j.cemco nres.2004.04.013

[25] Najim KB, Hall MR (2012) Mechanical and dynamic properties of self-compacting crumb rubber modified concrete. Constr Build Mater 27:521-530. https://doi.org/10.1016/j.conbu ildmat.2011.07.013

[26] OICA-International Organization of Motor Vehicle Manufacturers. Tyre. 2017. Available online: https://www.oica.net.

[27] Şahmaran M, Yaman İÖ, Tokyay M (2009) Transport and mechanical properties of self consolidating concrete with high volume fy ash. Cem Concr Compos 31:99-106. https:// doi.org/10.1016/j.cemconcomp.2008.12.003

[28] Siddique R, Naik TR (2004) Properties of concrete containing scrap-tyre rubber-an overview. Waste Manag 24:563-569. https://doi.org/10.1016/j.wasman.2004.01.006

[29] Skripkiūnas, G., Grinys, A., \& Černius, B. (2007). Deformation properties of concrete with rubber waste additives. Materials science [Medžiagotyra], 13(3), 219-223.

[30] Sofi A (2018) Effect of waste tyre rubber on mechanical and durability properties of concrete a review. Ain Shams Eng J 9:2691-2700. https://doi.org/10.1016/j.asej.2017.08.007 76.

[31] Taha M, El-Dieb A, El-Wahab M, Abdel-Hameed M (2008) Mechanical, fracture, and microstructural investigations of rubber concrete. J Mater Civ Eng 20:640-649 67.

[32] Topçu IB (1995) The properties of rubberized concretes. Cem Concr Res 25:304-310. https://doi.org/10.1016/0008- 8846(95)00014-3

[33] Uysal M, Sumer M (2011) Performance of self-compacting concrete containing diferent mineral admixtures. Constr Build Mater 25:4112-4120. https://doi.org/10.1016/j.conbuildma t.2011.04.032 45.

[34] Uysal M, Yilmaz K (2011) Effect of mineral admixtures on properties of self-compacting concrete. Cem Concr Compos 33:771-776

[35] WBCSD-World Business Council for Sustainable Development. Global ELT Management-A Global State of Knowledge on Collection Rates, Recovery Routes and Management Methods. 2018. Available online: https://www.wbcsd.org/ (accessed on 24 September 2018).

[36] Wong S, Ting S (2009) Use of recycled rubber tyres in normal and high-strength concretes. Mater J 106:325-332

[37] Yilmaz, A., \& Degirmenci, N. (2009). Possibility of using waste tyre rubber and fly ash with Portland cement as construction materials. Waste management, 29(5), 1541-1546.

[38] Zheng L, Sharon H, Yuan Y (2008) Strength, modulus of elasticity, and brittleness index of rubberized concrete. J Mater Civ Eng 20:692-699 68. 